\title{
FHIT promoter DNA methylation and expression analysis in childhood acute lymphoblastic leukemia
}

\author{
GHOLAMREZA BAHARI $^{1,2}$, MOHAMMAD HASHEMI ${ }^{1,2}$, \\ MAJID NADERI $^{3}$, SIMIN SADEGHI-BOJD ${ }^{3}$ and MOHSEN TAHERI ${ }^{4}$ \\ ${ }^{1}$ Cellular and Molecular Research Center; Departments of ${ }^{2}$ Clinical Biochemistry and ${ }^{3}$ Pediatrics; \\ ${ }^{4}$ Genetics of Non-Communicable Disease Research Center, Zahedan University of Medical Sciences, \\ Zahedan 98167-43181, Iran
}

Received June 24, 2016; Accepted June 16, 2017

DOI: $10.3892 / 01.2017 .6796$

\begin{abstract}
Fragile histidine triad (FHIT) is a tumor suppressor gene, which is involved in several malignancies. Epigenetic alterations in FHIT have been hypothesized to contribute to tumorigenesis. The present study aimed to examine DNA promoter methylation and gene expression levels of FHIT in childhood acute lymphoblastic leukemia (ALL), in a sample of Iranian patients. The promoter methylation status of FHIT was analyzed in 100 patients diagnosed with ALL and 120 healthy control patients. mRNA expression levels were assessed in 30 new cases of ALL compared with 32 healthy controls. Hypermethylation of the FHIT promoter was significantly more frequent in patients with ALL than in healthy controls $(\mathrm{OR}=3.83,95 \% \mathrm{CI}=1.51-9.75, \mathrm{P}=0.007)$. Furthermore, FHIT mRNA expression levels were significantly reduced in childhood ALL patients compared with healthy controls $(\mathrm{P}=0.032)$. The results of the present study revealed that dysregulation of the FHIT gene may contribute to the pathogenesis of childhood ALL. Future studies investigating a larger sample population with greater ethnic diversity would be beneficial, to confirm the results from the present study.
\end{abstract}

\section{Introduction}

Acute lymphoblastic leukemia (ALL) is the most common type of childhood cancer (1). In all cases of childhood leukemia, $\sim 80 \%$ are ALL, which represents $\sim 25 \%$ of cancers in children diagnosed $<15$ years of age in the United States in 2014 (2). Although the etiology of ALL is largely unknown, it has been proposed that multiple gene alterations, including inactivation of tumor suppressor genes, activation of proto-oncogenes and chromosomal rearrangements, in

Correspondence to: Professor Mohammad Hashemi, Department of Clinical Biochemistry, Zahedan University of Medical Sciences, Khalij Fars Boulevard, Zahedan 98167-43181, Iran

E-mail: hashemim@zaums.ac.ir

Key words: fragile histidine triad, methylation, gene expression addition to gene-environmental interplay, are involved in disease development $(1,3,4)$. Chromosomal abnormalities, including homozygous deletions and loss of heterozygosity, are among the most common characteristics of human tumors. The fragile histidine triad (FHIT) gene is located on the short arm of human chromosome-3 (3p14.2) which is a major site of chromosomal rearrangement (5).

FHIT protein has previously been proposed to act as a tumor suppressor (6-8). However, the exact mechanisms by which FHIT mediates its suppressive functions are not well understood. Several researchers have indicated that restoration of FHIT expression suppresses tumorigenicity, and transfection of FHIT in FHIT-deficient human cancer cells appears to induce apoptosis and inhibit cell growth (8-11). DNA hypermethylation may occur in genes involved in the cell cycle, DNA damage repair and signaling pathways. DNA methylation is a well-studied epigenetic modification, which significantly contributes to leukemia development (12). Several studies have demonstrated an association between FHIT hypermethylation and an increased risk of non-small-cell lung carcinoma (NSCLC) (13), breast cancer $(14,15)$, cervical cancer $(16)$, hepatocellular carcinoma (17) and thyroid carcinoma (18). Furthermore, downregulation of FHIT expression has been observed in acute lymphoblastic leukemia (ALL) (19), gastric cancer (20), colon adenocarcinoma (21), nasopharyngeal carcinoma (22) and colorectal cancer (23).

It has been proposed that the loss of normal FHIT function may be involved in the pathogenesis of several human leukemias, and the aberrant expression of FHIT is specific and frequent in leukemia samples $(24,25)$. The frequent loss of FHIT expression in ALL suggests that inactivating alterations at the FHIT locus may contribute to the development of leukemias (26). The present study aimed to assess promoter methylation status and expression levels of the FHIT gene in childhood ALL.

\section{Materials and methods}

Patients. A case-control study was conducted, in which 100 children diagnosed with ALL (54 male, 46 female; age, $5.5 \pm 3.6$ years) and 120 age and sex matched healthy controls (58 male, 62 female; age, 5.6 \pm 2.9 years) in Zahedan, Iran were 
Table I. Primer sequences for MS-PCR and RT-qPCR.

\begin{tabular}{|c|c|c|}
\hline Gene & Primers (5'-3') & Amplicon size (bp) \\
\hline Nested & $\begin{array}{l}\text { F: TTGATGGATTAAGTTAGGGATTGTAA } \\
\text { R: CCCCTACCTTCCAAAATATTAACA }\end{array}$ & 623 \\
\hline FHIT M & $\begin{array}{l}\text { F: TTTTCGTTTTTGTTTTTAGATAAGC } \\
\text { R: AAAAATATACCCACTAAATAACCGC }\end{array}$ & 157 \\
\hline FHIT U & $\begin{array}{l}\text { F: TGGTTTTTGTTTTTGTTTTTAGATAAGT } \\
\text { R: AAAATATACCCACTAAATAACCACC }\end{array}$ & 159 \\
\hline FHIT RT-qPCR & $\begin{array}{l}\text { F: ACCTGCGTCCTGATGAAGTG } \\
\text { R: CGTGAACGTGCTTCACAGTC }\end{array}$ & 144 \\
\hline GAPDH RT-qPCR & $\begin{array}{l}\text { F: GAAGGTGAAGGTCGGAGTC } \\
\text { R: GAAGATGGTGATGGGATTTC }\end{array}$ & 226 \\
\hline
\end{tabular}

MS-PCR, methylation specific polymerase chain reaction; RT-qPCR, reverse transcription-quantitative polymerase chain reaction; FHIT, fragile histidine triad; GAPDH, glyceraldehyde-3-phosphate dehydrogenase.

enrolled. All subjects were selected from the Ali-Ebne-Abitaleb Hospital, Zahedan University of Medical Sciences (Zahedan, Iran) between February 2013 and May 2014. Details of the study design and enrolment process have been previously described (27-29). Analysis of DNA methylation in the FHIT promoter was performed in 100 ALL cases and 120 healthy age and sex matched cases. Analysis of FHIT mRNA expression levels was conducted in 30 new cases of childhood ALL (20 males and 10 females; mean age, 5.5 53.4 years; age range, 1-15 years) and 32 healthy age and sex matched

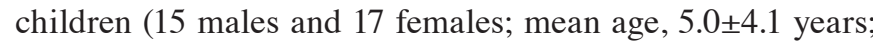
age range, 1-15 years). The subjects were selected from the Ali-Ebne-Abitaleb Hospital, Zahedan University of Medical Sciences (Zahedan, Iran) between February 2013 and May 2014. The local ethics committee of Zahedan University of Medical Sciences (Zahedan, Iran) approved the studies and written informed consent was obtained from parents of cases and controls.

Promoter methylation. A methylation specific PCR (MSP) technique was used for determination of promoter DNA methylation status. Whole blood samples $(2 \mathrm{ml})$ were collected in EDTA-containing tubes, and genomic DNA was extracted using the salting out method as described previously (30). DNA was modified by sodium bisulfite using the $\mathrm{CPGenome}^{\mathrm{TM}}$ Direct Prep Bisulfite Modification kit (Merck KGaA, Darmstadt, Germany). An MSP was established for the evaluation of FHIT promoter methylation. The primer sequences are listed in Table I. To each $0.2 \mathrm{ml}$ PCR reaction tube, $1 \mu 1$ bisulfite-converted DNA, $1 \mu 1$ of forward and reverse primer $(10 \mu \mathrm{M})$ and $17 \mu \mathrm{ldH} 2 \mathrm{O}$ were added with HotStart PCR PreMix (AccuPower, Bionner Corp, Daejean, South Korea). The PCR conditions were set as follows: $95^{\circ} \mathrm{C}$ for $5 \mathrm{~min}, 30$ cycles of $95^{\circ} \mathrm{C}$ for $30 \mathrm{sec}, 58^{\circ} \mathrm{C}$ for $30 \mathrm{sec}$, and $72^{\circ} \mathrm{C}$ for $30 \mathrm{sec}$, with a final extension step of $72^{\circ} \mathrm{C}$ for $5 \mathrm{~min}$. The PCR product (623 bp) was used as a template for MSP. MSP was performed using two pairs of primers; one pair specific for methylated and the other for unmethylated template (Table I). In each $0.2 \mathrm{ml}$ PCR reaction tube, $0.5 \mu l$ nested PCR product,

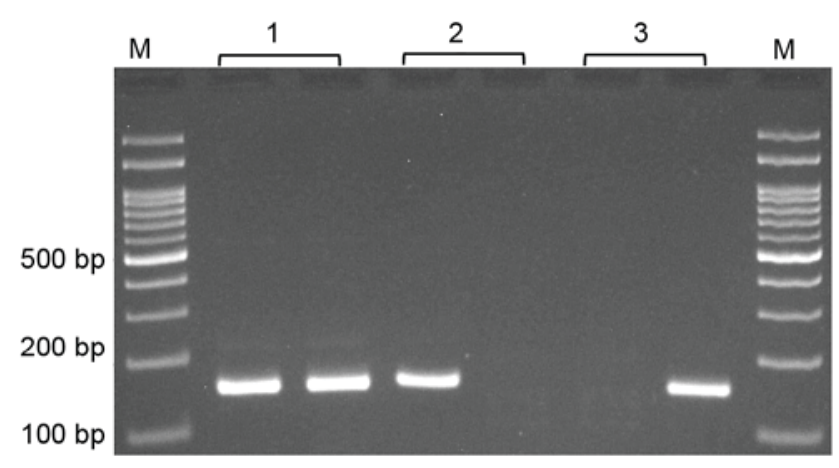

Figure 1. Electrophoresis pattern of promoter methylation of FHIT using methylation specific polymerase chain reaction. Lane 1, MU; lane 2, MM; lane 3, UU. M, DNA marker; FHIT, fragile histidine triad; MU, methylated unmethylated; MM, methylated methylated; UU, unmethylated unmethylated.

$1 \mu \mathrm{l}$ of each primer $(10 \mu \mathrm{M})$ and $10 \mu \mathrm{l} 2 \mathrm{X}$ Prime Taq Premix (GeNet Bio, Daejean, South Korea) and $7 \mu 1 \mathrm{dH} 2 \mathrm{O}$ were added. MSP conditions included an initial denaturation step at $95^{\circ} \mathrm{C}$ for $5 \mathrm{~min}$, followed by 30 cycles of $30 \mathrm{sec}$ at $95^{\circ} \mathrm{C}$, annealing at $58^{\circ} \mathrm{C}$ for $30 \mathrm{sec}$, and extension at $72^{\circ} \mathrm{C}$ for $30 \mathrm{sec}$, with a final extension step at $72^{\circ} \mathrm{C}$ for $5 \mathrm{~min}$. The methylated and unmethylated PCR products were 157 and 159 bp, respectively (Fig. 1).

Analysis of FHIT gene expression by RT-qPCR in patients with ALL and healthy controls. Total mRNA extraction from fresh whole blood was conducted using the commercially available kit, GeneJET RNA Purification kit (Thermo Fisher Scientific, Inc., Waltham, MA, USA) according to the manufacturer's protocol. cDNA synthesis was performed using the AccuPower CycleScript RT PreMix kit (Bioneer Corp., Daejeon, Korea) in a final volume of $20 \mu \mathrm{l}$ according to the manufacturer's protocol. The mRNA expression levels of FHIT and an internal control gene, glyceraldehyde-3-phosphate dehydrogenase $(G A P D H)$, were detected by qPCR using SYBR Green 2X RealQ Plus master mix (Amplicon; Bio, Korea; www.amplicon.com) on the ABI quantitative Real-Time PCR 
Table II. Promoter DNA methylation of the FHIT gene in patients with ALL and controls.

\begin{tabular}{|c|c|c|c|c|}
\hline Methylation status & Cases, n (\%) & Controls, n (\%) & OR $(95 \% \mathrm{CI})$ & $\mathrm{P}$-value \\
\hline Absent & $12(12.0)$ & $30(25.0)$ & 1.00 & \\
\hline Partial & $65(65.0)$ & $75(62.5)$ & $2.17(1.03-4.58)$ & $0.050^{\mathrm{a}}$ \\
\hline Present & $23(23.0)$ & $15(12.5)$ & $3.83(1.51-9.75)$ & $0.007^{\mathrm{a}}$ \\
\hline Partial + present & $88(88.0)$ & $90(75.0)$ & $2.44(1.18-5.08$ & $0.016^{\mathrm{a}}$ \\
\hline
\end{tabular}

${ }^{\mathrm{a}} \mathrm{P}<0.05$. OR, odds ratio; $\mathrm{CI}$, confidence interval.

system (Applied Biosystems, Thermo Fisher Scientific, Inc.). All primer sequences are presented in Table I. To each $0.2 \mathrm{ml}$ PCR reaction tube, $1 \mu \mathrm{l}$ of cDNA, $1 \mu \mathrm{l}$ of forward and reverse primers, $10 \mu 1$ 2X RealQ Plus Master Mix Green High Rox

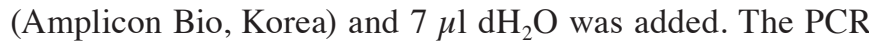
conditions were set as follows: $95^{\circ} \mathrm{C}$ for $6 \mathrm{~min}, 40$ cycles of $95^{\circ} \mathrm{C}$ for $40 \mathrm{sec}, 63^{\circ} \mathrm{C}$ for $40 \mathrm{sec}$, and $72^{\circ} \mathrm{C}$ for $35 \mathrm{sec}$, with a final extension step of $72^{\circ} \mathrm{C}$ for $10 \mathrm{~min}$. Results are presented as gene expression fold change of ALL samples compared with controls, according to the $2^{-\Delta \Delta C q}$ method (31).

Statistical analysis. Statistical analysis was performed using SPSS 20.0 software (IBM Corp., Armonk, NY, USA). Data were analyzed using an independent sample t-test for continuous data and Fisher's exact test or $\chi^{2}$ test for categorical data. The odds ratio (OR) and 95\% confidence intervals (CI) were calculated from logistic regression analysis to identify the associations between methylation status and ALL. $\mathrm{P}<0.05$ was considered to indicate a statistically significant difference.

\section{Results}

The case-control study was conducted on 100 childhood ALL cases (54 male, 46 female; age, $5.5 \pm 3.6$ years) and 120 healthy children (58 male, 62 female; age, $5.6 \pm 2.9$ years). No significant differences were observed between groups regarding sex and age ( $\mathrm{P}=0.419$ and 0.761 , respectively). Table II presents the promoter DNA methylation status of the FHIT gene in patients with ALL and controls. The frequency distribution of non-methylation, partial methylation and hypermethylation in cases and controls were $12.0,65.0$, and $23.0 \%$, and 25.0, 62.5, and $12.5 \%$, respectively. Hypermethylation of the FHIT gene was significantly more frequent in children with ALL than in healthy controls $(\mathrm{OR}=3.83,95 \% \mathrm{CI}=1.51-9.75, \mathrm{P}=0.007)$. FHIT mRNA expression levels in ALL cases and controls are presented in Fig. 2. These results revealed that the gene expression of FHIT was significantly downregulated in ALL cases compared with that in healthy children $(1.231 \pm 0.204$ vs. 2.124 $\pm 0.349 ; \mathrm{P}=0.032$ ).

\section{Discussion}

FHIT is a candidate tumor suppressor gene in multiple types of cancer, although the mechanism of tumor suppression by FHIT is not fully understood. Several investigations have revealed that FHIT overexpression leads to the activation of the two main apoptotic pathways, the extrinsic caspase- 8 pathway and

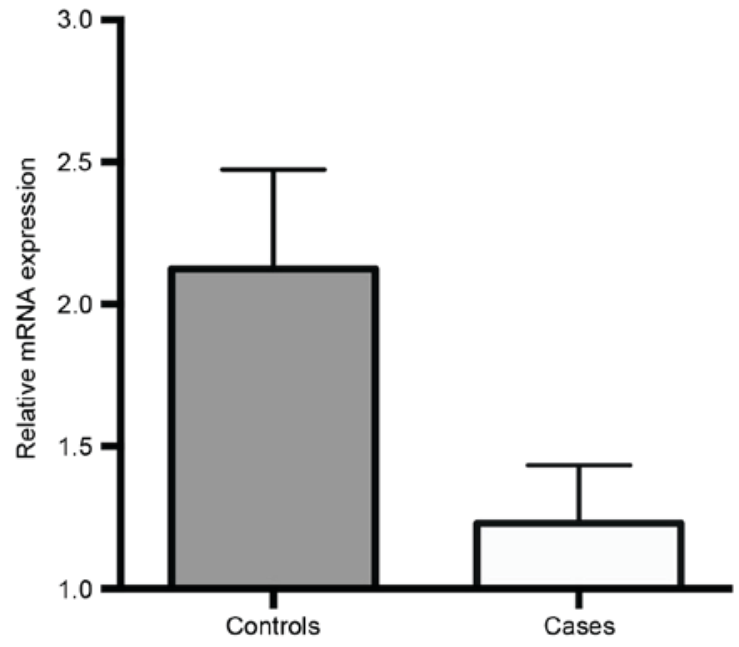

Figure 2. Relative mRNA expression of FHIT in patients with childhood ALL and controls. mRNA expression levels of FHIT were significantly downregulated in ALL $(\mathrm{P}=0.032)$. Statistical analysis was performed using an unpaired t-test with Welch's correction. FHIT, fragile histidine triad; ALL, acute lymphoblastic leukeamia.

the intrinsic mitochondrial pathway (32-34). The inactivation of programmed cell death may lead to tumorigenesis (35).

In the present study, hypermethylation of the FHIT gene was demonstrated to be significantly more frequent in children with ALL than in healthy controls. Furthermore, the gene expression of FHIT was significantly lower in patients with childhood ALL compared with healthy controls. The results of the present study indicated that epigenetic modifications and altered gene expression of FHIT in childhood ALL, may contribute to the development of this disease.

In agreement with results of the present study, Malak et al (19) demonstrated that the expression of FHIT was significantly lower in childhood ALL compared with healthy children. In addition, Chen et al (36) reported that mRNA expression of FHIT was significantly lower and methylation frequency of FHIT was significantly higher in ALL samples compared with controls.

Previous studies have provided evidence that DNA methylation is the most commonly detected alteration in adult ALL (37-40). Genome-wide DNA methylation profiles are commonly altered in pediatric ALL (41). It has been demonstrated that hypermethylation of multiple genes may be involved in the relapse of childhood ALL (42). Suppression of FHIT may be involved in the development of rearranged acute lymphoblastic leukemia, an aggressive type of ALL (43). 
A meta-analysis performed by Wu et al (13) indicated that FHIT hypermethylation, which induces the inactivation of the FHIT gene, is associated with an increased risk and adverse clinical outcome of NSCLC. It has been demonstrated that FHIT promoter hypermethylation is associated with the development of breast cancer and certain poor prognostic features of the disease (14). FHIT may be a potential drug target for the development of demethylation treatment for patients with breast cancer (44). Furthermore, hypermethylation of the FHIT promoter was previously demonstrated to be involved in the development and transformation of fetal mesenchymal stem cells into F6 tumor cells (45). In conclusion, the results of the present study suggested that hypermethlation and mRNA downregulation of FHIT gene may be involved in the development of pediatric ALL. Further studies are required to reveal the exact role of FHIT on ALL risk.

\section{Acknowledgements}

The present study was supported by a dissertation grant (no. 6858) from the Zahedan University of Medical Sciences.

\section{References}

1. Belson M, Kingsley B and Holmes A: Risk factors for acute leukemia in children: A review. Environ Health Perspect 115: 138-145, 2007.

2. Ward E, DeSantis C, Robbins A, Kohler B and Jemal A: Childhood and adolescent cancer statistics, 2014. CA Cancer J Clin 64: 83-103, 2014.

3. Guo LM, Xi JS, Ma Y, Shao L, Nie CL and Wang GJ: ARID5B gene rs10821936 polymorphism is associated with childhood acute lymphoblastic leukemia: A meta-analysis based on 39,116 subjects. Tumour Biol 35: 709-713, 2014.

4. Ma Y, Sui Y, Wang L and Li H: Effect of GSTM1 null genotype on risk of childhood acute leukemia: A meta-analysis. Tumour Biol 35: 397-402, 2014

5. Pekarsky Y, Zanesi N, Palamarchuk A, Huebner K and Croce CM: FHIT: From gene discovery to cancer treatment and prevention. Lancet Oncol 3: 748-754, 2002.

6. Ohta M, Inoue H, Cotticelli MG, Kastury K, Baffa R, Palazzo J, Siprashvili Z, Mori M, McCue P, Druck T, et al: The FHIT gene, spanning the chromosome 3p14.2 fragile site and renal carcinoma-associated $\mathrm{t}(3 ; 8)$ breakpoint, is abnormal in digestive tract cancers. Cell 84: 587-597, 1996.

7. Brenner C, Bieganowski P, Pace HC and Huebner K: The histidine triad superfamily of nucleotide-binding proteins. J Cell Physiol 181: 179-187, 1999.

8. Siprashvili Z, Sozzi G, Barnes LD, McCue P, Robinson AK, Eryomin V, Sard L, Tagliabue E, Greco A, Fusetti L, et al: Replacement of Fhit in cancer cells suppresses tumorigenicity. Proc Natl Acad Sci USA 94: 13771-13776, 1997.

9. Ji L, Fang B, Yen N, Fong K, Minna JD and Roth JA: Induction of apoptosis and inhibition of tumorigenicity and tumor growth by adenovirus vector-mediated fragile histidine triad (FHIT) gene overexpression. Cancer Res 59: 3333-3339, 1999.

10. Sard L, Accornero P, Tornielli S, Delia D, Bunone G, Campiglio M, Colombo MP, Gramegna M, Croce CM, Pierotti MA and Sozzi G: The tumor-suppressor gene FHIT is involved in the regulation of apoptosis and in cell cycle control. Proc Natl Acad Sci USA 96: 8489-8492, 1999.

11. Sevignani C, Calin GA, Cesari R, Sarti M, Ishii H, Yendamuri S, Vecchione A, Trapasso F and Croce CM: Restoration of fragile histidine triad (FHIT) expression induces apoptosis and suppresses tumorigenicity in breast cancer cell lines. Cancer Res 63: 1183-1187, 2003.

12. Agrawal S, Unterberg M, Koschmieder S, zur Stadt U, Brunnberg U, Verbeek W, Büchner T, Berdel WE, Serve H and Müller-Tidow C: DNA methylation of tumor suppressor genes in clinical remission predicts the relapse risk in acute myeloid leukemia. Cancer Res 67: 1370-1377, 2007.
13. Wu X, Wu G, Yao X, Hou G and Jiang F: The clinicopathological significance and ethnic difference of FHIT hypermethylation in non-small-cell lung carcinoma: A meta-analysis and literature review. Drug Des Devel Ther 10: 699-709, 2016.

14. Zaki SM, Abdel-Azeez HA, El Nagar MR, Metwally KA and S Ahmed MM: Analysis of FHIT gene methylation in egyptian breast cancer women: Association with clinicopathological features. Asian Pac J Cancer Prev 16: 1235-1239, 2015.

15. Liu L, Sun L, Li C, Li X, Zhang Y, Yu Y and Xia W: Quantitative detection of methylation of FHIT and BRCA1 promoters in the serum of ductal breast cancer patients. Biomed Mater Eng 26 (Suppl 1): S2217-S2222, 2015.

16. Banzai C, Nishino K, Quan J, Yoshihara K, Sekine M, Yahata T and Tanaka K; Gynecological Cancer Registry of Niigata: Promoter methylation of DAPK1, FHIT, MGMT, and CDKN2A genes in cervical carcinoma. Int J Clin Oncol 19: 127-132, 2014.

17. Zhang X, Li HM, Liu Z, Zhou G, Zhang Q, Zhang T, Zhang J and Zhang C: Loss of heterozygosity and methylation of multiple tumor suppressor genes on chromosome 3 in hepatocellular carcinoma. J Gastroenterol 48: 132-143, 2013.

18. Yin DT, Wang L, Sun J, Yin F, Yan Q, Shen R, He G and Gao JX: Association of the promoter methylation and protein expression of Fragile Histidine Triad (FHIT) gene with the progression of differentiated thyroid carcinoma. Int J Clin Exp Pathol 3: 482-491, 2010.

19. Malak CA, Elghanam DM and Elbossaty WF: FHIT gene expression in acute lymphoblastic leukemia and its clinical significance. Asian Pac J Cancer Prev 16: 8197-8201, 2015.

20. Liao J, Wen S, Cao L, Zhou Y and Feng Z: Effect of eradication of Helicobacter pylori on expression levels of FHIT, IL-8 and P73 in gastric mucosa of first-degree relatives of gastric cancer patients. PLoS One 10: e0124576, 2015.

21. Kapitanović S, Čačev T, Lončar B, Catela Ivković T, Križanac Š and Pavelić K: Reduced FHIT expression is associated with tumor progression in sporadic colon adenocarcinoma. Exp Mol Pathol 96: 92-97, 2014.

22. Chen X, Li P, Yang Z and Mo WN: Expression of fragile histidine triad (FHIT) and WW-domain oxidoreductase gene (WWOX) in nasopharyngeal carcinoma. Asian Pac J Cancer Prev 14: 165-171, 2013.

23. Al-Temaimi RA, Jacob S, Al-Ali W, Thomas DA and Al-Mulla F: Reduced FHIT expression is associated with mismatch repair deficient and high $\mathrm{CpG}$ island methylator phenotype colorectal cancer. J Histochem Cytochem 61: 627-638, 2013.

24. Sugimoto K, Yamada K, Miyagawa K, Hirai H and Oshimi K: Decreased or altered expression of the FHIT gene in human leukemias. Stem Cells 15: 223-228, 1997.

25. Iwai T, Yokota S, Nakao M, Nakazawa N, Taniwaki M, Kimura T, Sonoda Y, Kaneko H, Okuda T, Azuma H, et al: Frequent aberration of FHIT gene expression in acute leukemias. Cancer Res 58: 5182-5187, 1998

26. Hallas C, Albitar M, Letofsky J, Keating MJ, Huebner K and Croce CM: Loss of FHIT expression in acute lymphoblastic leukemia. Clin Cancer Res 5: 2409-2414, 1999.

27. Hashemi M, Sheybani-Nasab M, Naderi M, Roodbari F and Taheri M: Association of functional polymorphism at the miR-502-binding site in the $3^{\prime}$ untranslated region of the SETD8 gene with risk of childhood acute lymphoblastic leukemia, a preliminary report. Tumour Biol 35: 10375-10379, 2014.

28. Hasani SS, Hashemi M, Eskandari-Nasab E, Naderi M, Omrani M and Sheybani-Nasab M: A functional polymorphism in the miR-146a gene is associated with the risk of childhood acute lymphoblastic leukemia: A preliminary report. Tumour Biol 35: 219-225, 2014.

29. Hashemi M, Ebrahimi M, Amininia S, Naderi M, EskanadriNasab E and Taheri M: Evaluation of rs3102735 and rs2073617 osteoprotegerin gene polymorphisms and the risk of childhood acute lymphocytic leukemia in Zahedan Southeast Iran. Int J Hematol Oncol Stem Cell Res 8: 39-44, 2014.

30. Hashemi M, Moazeni-Roodi AK, Fazaeli A, Sandoughi M, Bardestani GR, Kordi-Tamandani DM and Ghavami S: Lack of association between paraoxonase-1 Q192R polymorphism and rheumatoid arthritis in southeast Iran. Genet Mol Res 9: 333-339, 2010.

31. Livak KJ and Schmittgen TD: Analysis of relative gene expression data using real-time quantitative PCR and the 2(-Delta Delta C(T)) method. Methods 25: 402-408, 2001. 
32. Ishii H, Dumon KR, Vecchione A, Trapasso F, Mimori K, Alder H, Mori M, Sozzi G, Baffa R, Huebner K and Croce CM: Effect of adenoviral transduction of the fragile histidine triad gene into esophageal cancer cells. Cancer Res 61: 1578-1584, 2001 .

33. Roz L, Gramegna M, Ishii H, Croce CM and Sozzi G: Restoration of fragile histidine triad (FHIT) expression induces apoptosis and suppresses tumorigenicity in lung and cervical cancer cell lines. Proc Natl Acad Sci USA 99: 3615-3620, 2002.

34. Dumon KR, Ishii H, Vecchione A, Trapasso F, Baldassarre G, Chakrani F, Druck T, Rosato EF, Williams NN, Baffa R, et al: Fragile histidine triad expression delays tumor development and induces apoptosis in human pancreatic cancer. Cancer Res 61: 4827-4836, 2001.

35. Ghavami S, Hashemi M, Ande SR, Yeganeh B, Xiao W, Eshraghi M, Bus CJ, Kadkhoda K, Wiechec E, Halayko AJ and Los M: Apoptosis and cancer: Mutations within caspase genes. J Med Genet 46: 497-510, 2009.

36. Chen X, Zhang H, Li P, Yang Z, Qin L and Mo W: Gene expression of WWOX, FHIT and p73 in acute lymphoblastic leukemia Oncol Lett 6: 963-969, 2013.

37. Garcia-Manero G, Daniel J, Smith TL, Kornblau SM, Lee MS, Kantarjian HM and Issa JP: DNA methylation of multiple promoter-associated $\mathrm{CpG}$ islands in adult acute lymphocytic leukemia. Clin Cancer Res 8: 2217-2224, 2002.

38. Yang Y, Takeuchi S, Hofmann WK, Ikezoe T, van Dongen JJ, Szczepański T, Bartram CR, Yoshino N, Taguchi H and Koeffler HP: Aberrant methylation in promoter-associated $\mathrm{CpG}$ islands of multiple genes in acute lymphoblastic leukemia. Leuk Res 30: 98-102, 2006.

39. Garcia-Manero G, Yang H, Kuang SQ, O'Brien S, Thomas D and Kantarjian H: Epigenetics of acute lymphocytic leukemia. Semin Hematol 46: 24-32, 2009.
40. Paulsson K, An Q, Moorman AV, Parker H, Molloy G, Davies T, Griffiths M, Ross FM, Irving J, Harrison CJ, et al: Methylation of tumour suppressor gene promoters in the presence and absence of transcriptional silencing in high hyperdiploid acute lymphoblastic leukaemia. Br J Haematol 144: 838-847, 2009.

41. Chatterton Z, Morenos L, Mechinaud F, Ashley DM, Craig JM, Sexton-Oates A, Halemba MS, ParkinsonBates M, Ng J, Morrison D, et al: Epigenetic deregulation in pediatric acute lymphoblastic leukemia. Epigenetics 9: 459-467, 2014.

42. Matsushita C, Yang Y, Takeuchi S, Matsushita M, Van Dongen JJ, Szczepanski T, Bartram CR, Seo H, Koeffler HP and Taguchi H: Aberrant methylation in promoter-associated $\mathrm{CpG}$ islands of multiple genes in relapsed childhood acute lymphoblastic leukemia. Oncol Rep 12: 97-99, 2004.

43. Stam RW, den Boer ML, Passier MM, Janka-Schaub GE, Sallan SE, Armstrong SA and Pieters R: Silencing of the tumor suppressor gene FHIT is highly characteristic for MLL gene rearranged infant acute lymphoblastic leukemia. Leukemia 20: 264-271, 2006.

44. Su Y, Wang X, Li J, Xu J and Xu L: The clinicopathological significance and drug target potential of FHIT in breast cancer, a meta-analysis and literature review. Drug Des Devel Ther 9: 5439-5445, 2015.

45. Xu XJ, Gao S, Wang M, Qian H, Gu GY, Zhang K and Xu WR: Methylation status of the gene in the transformed human mesenchymal F6 stem cell line. Oncol Lett 9: 2661-2666, 2015. 